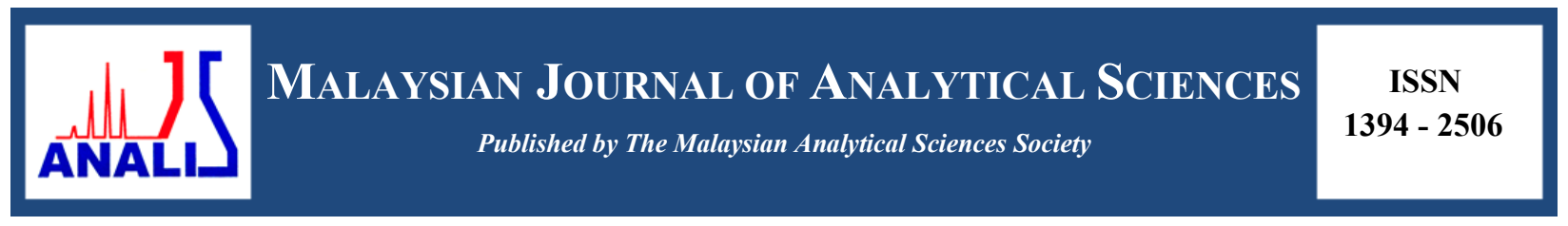

\title{
MICROWAVE-ASSISTED SYNTHESIS OF MESOPOROUS SILICA NANOPARTICLES AS A DRUG DELIVERY VEHICLE
}

\author{
(Sintesis Partikel Nano Silika Berliang Meso Dibantu Gelombang Mikro Sebagai Medium \\ Penyebaran Ubat)
}

\author{
Nur Hidayatul Nazirah Kamarudin ${ }^{1}{ }^{*}$, Aishah Abdul Jalil ${ }^{2,3}$, Sugeng Triwahyono ${ }^{4}$, Sharifah Najiha Timmiati ${ }^{5}$ \\ ${ }^{I}$ Department of Chemical and Process Engineering, Faculty of Engineering and Built Environment, \\ Universiti Kebangsaan Malaysia, 43600 UKM Bangi, Selangor, Malaysia \\ ${ }^{2}$ Department of Chemical Engineering, Faculty of Chemical and Energy Engineering \\ ${ }^{3}$ Centre of Hydrogen Energy, Institute of Future Energy \\ ${ }^{4}$ Department of Chemistry, Faculty of Science \\ Universiti Teknologi Malaysia, 81310 UTM Johor Bahru, Johor, Malaysia \\ ${ }^{5}$ Institute of Fuel Cell, \\ Universiti Kebangsaan Malaysia, 43600 UKM Bangi, Selangor, Malaysia \\ *Corresponding author: nhnazirah@ukm.edu.my
}

Received: 21 October 2015; Accepted: 14 June 2016

\begin{abstract}
Nanotechnology has been utilized in medicine for therapeutic drug delivery and the development of treatments for a variety of diseases and disorders. Mesoporous silica nanoparticles (MSN), which combine both unique properties of nanomaterials and mesostructured substances, have aroused special attention in biomedical research field due to its great advantages in many aspects such as well biocompatible, unique properties of tunable pore size and structure, large surface areas and pore volumes, controllable morphology and modifiable surfaces, high chemical and thermal stabilities. In this study, the microwave was utilized to synthesize MSN under $100 \mathrm{~W}, 300 \mathrm{~W}$ and $450 \mathrm{~W}$ heating powers. All MSNs was tested for adsorption and release of an anti-inflammatory and anti-cancer drug, ibuprofen. The characterization revealed that the MSN prepared under $450 \mathrm{~W}$ (MSN450) produced the most ordered and prominent mesoporous structure compared to lower power applied. MSN450 exhibited the highest ibuprofen adsorption, followed by MSN300 and MSN100, confirming that more ordered MSN demonstrated higher adsorptivity toward ibuprofen. For the release study, MSN450 showed the slowest release rate of ibuprofen, followed by MSN300 and MSN100. All MSNs was found to exhibit good activity for the ibuprofen adsorption and release.
\end{abstract}

Keywords: microwave, mesoporous silica, ibuprofen, adsorption, drug delivery

\begin{abstract}
Abstrak
Teknologi nano telah digunakan dalam bidang perubatan untuk penyampaian ubat terapeutik dan pembangunan rawatan untuk pelbagai penyakit dan gangguan. Partikel nano silika mesoliang, yang menggabungkan kedua-dua ciri-ciri yang unik bahan nano dan bahan struktur meso, telah membangkitkan perhatian khusus dalam bidang penyelidikan bioperubatan kerana kelebihan yang besar dalam banyak aspek seperti bioserasi, ciri-ciri unik bolehubah saiz liang dan struktur, kawasan permukaan dan isipadu liang yang besar, morfologi bolehkawal dan permukaan boleh ubahsuai, serta tinggi kestabilan kimia dan haba. Dalam kajian ini, gelombang mikro telah digunakan untuk mensintesis partikel nano silika mesoliang (MSN) dibawah kuasa pemanasan $100 \mathrm{~W}$, $300 \mathrm{~W}$ dan $450 \mathrm{~W}$. Semua MSN telah diuji untuk penjerapan dan pembebasan ubat anti-radang dan anti-kanser, ibuprofen. Pencirian mendedahkan bahawa MSN yang disediakan di bawah $450 \mathrm{~W}\left(\mathrm{MSN}_{450}\right)$ menghasilkan struktur paling tersusun dan terbaik dibandingkan dengan kuasa lebih rendah. $\mathrm{MSN}_{450}$ telah mencapai penjerapan ibuprofen tertinggi, diikuti dengan $\mathrm{MSN}_{300}$ dan $\mathrm{MSN}_{100}$, mengesahkan bahawa MSN yang lebih tersusun menunjukkan penjerapan ibuprofen lebih tinggi. Untuk kajian
\end{abstract}




\section{Nur Hidayatul Nazirah et al: MICROWAVE-ASSISTED SYNTHESIS OF MESOPOROUS SILICA NANOPARTICLES AS A DRUG DELIVERY VEHICLE}

pembebasan, $\mathrm{MSN}_{450}$ menunjukkan kadar pembebasan ibuprofen paling rendah, diikuti dengan $\mathrm{MSN}_{300}$ dan $\mathrm{MSN}_{100}$. Semua MSN ditemui mencapai keaktifan yang baik untuk penjerapan dan pembebasan ibuprofen.

Kata kunci: gelombang mikro, silica berliang meso, ibuprofen, penjerapan, penyampaian ubat

\section{Introduction}

In recent years, mesoporous silica nanoparticles (MSNs) have been well developed as effective drug storage vehicles in drug delivery systems due to their large pore volume $\left(\sim 1 \mathrm{~cm}^{3} / \mathrm{g}\right)$, high surface area $\left(>1000 \mathrm{~m}^{2} / \mathrm{g}\right)$, ease of functionalization, low toxicity and biodegradability [1-3]. Exclusively in drug delivery, mesoporous silica is often used with modification to suit treatment needs. The study of the loading and release of drugs into/from mesoporous silica is in high demand for the development of tissue regeneration, transdermal therapy, and cell regulation due to the biocompatibility of this material.

The traditional synthesis method of mesoporous materials is the hydrothermal route, which uses a certain number of surfactants, as well as acid or alkali to compose a mixed aqueous preparation. Next, inorganic sources are added and heated to crystallize, followed by filtration, drying, and calcination or extraction to remove the template. Although finely ordered mesoporous materials are obtained, the process is time and energy consuming [4]. Heating solids in the conventional system leads to an uneven temperature distribution due to poor heat transfer into the bulk of the material. The outer temperature may be substantially higher than the inner one, because the material itself acts as an insulator. In these modern days where scientific findings and technology go hand in hand, any improvement to a synthesis technique that saves time in the synthesis of new materials or improves the properties of materials would be extremely beneficial. It is known that hydrothermal synthesis of inorganic materials using microwave (MW) heating promotes nucleation and can reduce the synthesis time and particle size significantly in comparison with the conventional convection heating method [5-6]. Besides, with faster polymerization under MW irradiation, it was also found that the swelling rate of the material was much higher compared to a material prepared by conventional heating.

In this study, we synthesized the MSN by co-condensation methods, and the physicochemical properties of the MSNs were characterized using X-ray powder diffractometer (XRD), Transmission Electron Microscopy (TEM), and Field Emission Scanning Electron Microscopy (FESEM). The performances of the three MSNs were then examined on the adsorption and release of ibuprofen, a non-steroidal anti-inflammatory drug widely used in the treatment of pain and inflammation in rheumatic disease and other musculoskeletal disorders. Millions of kilograms of ibuprofen are produced and consumed annually by humans; thus, the application of MSN to ibuprofen delivery is crucial and ever continuing research [7]. The influences of structure and morphologies of the MSNs towards the model drug delivery system were discussed in brief.

\section{Materials and Methods}

Cetyltrimethylammonium bromide (CTAB), ethylene glycol (EG), and tetraethyl orthosilicate (TEOS) were purchased from Merck Sdn Bhd, Malaysia. Ammonium hydroxide $\left(\mathrm{NH}_{4} \mathrm{OH}\right)$ was obtained from QRec, Malaysia. The synthesis procedure was as follows. $\mathrm{CTAB}, \mathrm{EG}$, and $\mathrm{NH}_{4} \mathrm{OH}$ were dissolved in $700 \mathrm{~mL}$ of water. After vigorous heating, TEOS were added to the mixture to give a white micelle solution. After stirring for 2 hours, the white solution was moved into a beaker and deposited in the microwave oven under heating power settings of 100 , 300 , and $450 \mathrm{~W}$ in 8,4 and 1 hour, respectively. The variation of time was decided according to the complete evaporation of the solvent mixture for the purpose of shorten the drying time before preceded to calcination. The mixture was kept under continuous stirring and the sample was collected by centrifugation. The obtained gel was heated at $110^{\circ} \mathrm{C}$ for 24 hours followed by calcination at $550{ }^{\circ} \mathrm{C}$.

The crystallinity of catalysts was measured with a Bruker Advance D8 X-ray powder diffractometer with Cu K $\alpha(\lambda$ $=1.5418 \AA$ ) radiation as the diffracted monochromatic beam at $40 \mathrm{kV}$ and $40 \mathrm{~mA}$. Transmission electron microscopy (TEM) was carried out using a JEOL JEM-2100F micro-scope. The samples were ultrasonically dispersed in acetone and deposited on an amorphous, porous carbon grid. The surface morphology and surface 
elemental analysis of the samples were performed using FESEM-EDX (JEOL JSM-6701F) with an accelerating voltage of $15 \mathrm{kV}$. The samples were coated with platinum by electro-deposition under vacuum prior to analyses.

Powdered mesoporous samples were loaded with ibuprofen by soaking them into an ethanol solution of ibuprofen followed by continuous stirring for 24 hours at $310 \mathrm{~K}$. Ibuprofen loaded samples were recovered by filtration, washed with ethanol and dried for 24 hours at $313 \mathrm{~K}$. During the process, aliquots of $2 \mathrm{~mL}$ were withdrawn at predetermined time intervals and centrifuged in a Hettich Zentrifugen Micro 120 before being analyzed by UV-Vis spectrophotometer (Agilent Technologies) to determine the residual concentration of ibuprofen. Each set of experiments was performed three times. The adsorption band of ibuprofen was taken at a maximum wavelength $\left(\lambda_{\max }\right)$ of $264 \mathrm{~nm}$. The ibuprofen release profile was obtained by adding the drug-impregnated powders in a simulated body fluid (SBF) at $37{ }^{\circ} \mathrm{C}$ under continuous stirring. The drug concentration in the release fluid for the different release time was determined using UV/VIS spectrophotometer.

\section{Results and Discussion}

Figure 1 shows FESEM and TEM images of the MSNs at different microwave power levels, respectively. Comparing the three MSNs in Fig. 1 ( $a, b, c)$ FESEM analysis revealed spherical particles with smooth surface for the MSN prepared at microwave power of $450 \mathrm{~W}$; however, irregular particles with a rough surface were formed at a microwave power of $100 \mathrm{~W}$. Moreover, the TEM images in Fig 1 (d, e, f) shows clusters of hexagonally-ordered silica nanoparticles approximately $30-45 \mathrm{~nm}$ in size. The average particle sizes and ordering of the hexagonal silica were increased with increasing microwave power, since $\mathrm{MSN}_{450}$ exhibited more visible long-range silica arrangement. This may be due to the enhanced assembly of parallel CTAB chains upon increasing the microwave power, which resulted in an increased of silica hydrolysis; thus, a more ordered silica arrangement was formed compared to the MSN prepared at a low microwave power [8].



Figure 1. FESEM images of (a)MSN $\mathrm{MSO}_{100}$; (b)MSN $\mathrm{MS}_{300}$; (c) $\mathrm{MSN}_{450}$; and TEM image of (d)MSN $\mathrm{MSO}_{100}$; (e)MSN $\mathrm{MSO}_{300}$; (f) $\mathrm{MSN}_{450}$ 


\section{Nur Hidayatul Nazirah et al: MICROWAVE-ASSISTED SYNTHESIS OF MESOPOROUS SILICA NANOPARTICLES AS A DRUG DELIVERY VEHICLE}

Hence, it can be stated that the crystal growth of MSN was greatly influenced by the microwave power, which resulted in different morphology and particle sizes. It is presumed that these properties will affect MSN behavior regarding ibuprofen adsorption [9]. Indeed, the microwave synthesis of MCM-41 has been reported earlier [10]. In the report, the MCM-41 was synthesized by the composition of synthesis materials of CTAB, TMAOH, TEOS and $\mathrm{H}_{2} \mathrm{O}$, while MSN was synthesized using CTAB, ethylene glycol, $\mathrm{NH}_{4} \mathrm{OH}$, TEOS and $\mathrm{H}_{2} \mathrm{O}$. Different particle size was obtained, which is $100 \mathrm{~nm}$ for the former, and $30-45 \mathrm{~nm}$ for the latter. This may be due to the difference in the composition led to the different crystal growth for both materials.

Figure 2 demonstrates the difference in the hexagonal density of all MSNs in the low $2 \theta$ region. The pattern illustrates the reflection of a typical MCM-41 type material, which consists of an ordered hexagonal array of parallel silica tubes and can be indexed assuming a hexagonal unit cell as (100), (110), and (200) [11]. Since the materials were not crystalline at the atomic level, no reflections were observed at higher angles.

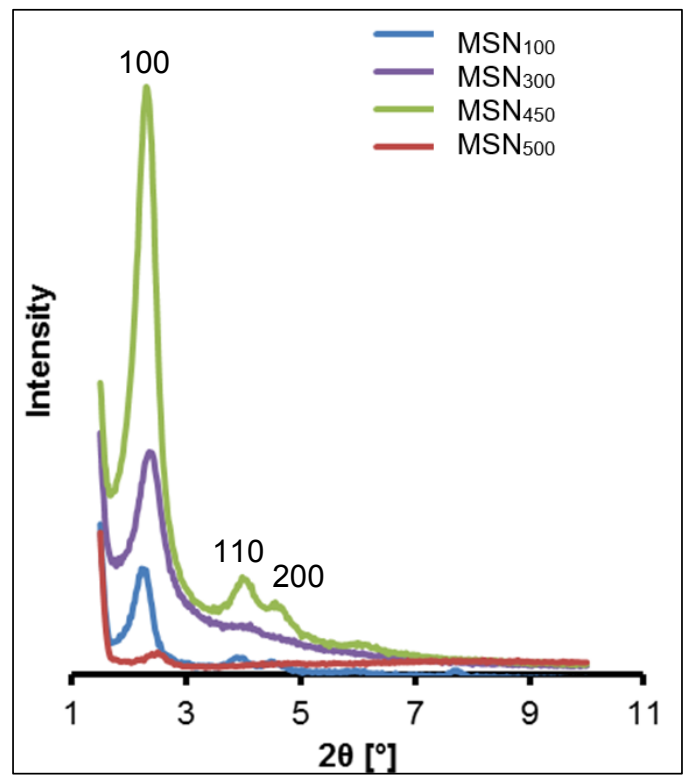

Figure 2. X-ray diffraction patterns of all MSNs

A substantial increment of the diffraction peak intensity corresponding to the (100) reflection was observed upon increasing the microwave power from 100 to $450 \mathrm{~W}$, indicating the alteration of the long-range ordering of the mesoporous structure, while the MSN structure was unchanged. Although the appropriate synthesis time was given to all of the MSN for well crystal growth, the MSN prepared under $450 \mathrm{~W}$ exhibited higher crystallinity and silica order as compared to $300 \mathrm{~W}$ and $100 \mathrm{~W}$. This may be related to the higher instantaneous microwave power delivery and consequently higher microwave electric field at $450 \mathrm{~W}$ during synthesis. While the microwave power was also further increased up to $500 \mathrm{~W}$ but disordered structure was obtained, this may be due to the fast drying (30 min) led to the incomplete condensation of TEOS and molecular assembly.

A similar observation was reported for the synthesis of iron-platinum nanoparticles using variable microwave power, in which the XRD data revealed an increase in the peak intensity upon increasing the microwave power from 120 to $420 \mathrm{~W}$ [12]. After increasing microwave power, the degree of hydration of the CTAB chains may also increase and their interaction with silica species in the solution becomes stronger, in combination with the increasing rate of hydrolysis and polymerization of the TEOS source that led to the formation of more ordered silica. This may also be related to the effect of synthesis temperature, wherein the temperature rapidly rose when the 
microwaves coupled directly with the molecules of the entire reaction mixture, which led to the instantaneous localized superheating of the substance [13]. A less ordered structure of SBA-16 prepared at a lower temperature was reported due to the low degree of Pluronic F127 chain hydration, which resulted in weaker interactions with the silica species [14].

Based on the characterization results, the mechanism for the formation of MSNs using microwaves is proposed. The use of microwave power of $100 \mathrm{~W}$ seemed inadequate since it formed poorly crystalline, irregular mesoporous MSN structures with a small surface area. Since to the electromagnetic field generated by microwaves affects the enhancement of crystal growth, a low microwave power with a short irradiation time was probably insufficient to provide the homogeneous heating required for optimal crystal growth [15]. The irregularities in the structure were presumed to be a consequence of the formation of "hot spots" at certain locations in the microwave reactor.

A similar result was reported regarding the disruption of the ferrite structure due to "hot spots" or areas that induce a localized enhancement in the reaction rate [9]. On the contrary, the use of a microwave power of $450 \mathrm{~W}$ generated a more homogeneous and uniform silica order. Although the "hot spots" phenomenon also occurred at $450 \mathrm{~W}$, it is presumed that the strong thermal supply directed the micelles to accumulate faster than at $100 \mathrm{~W}$ of microwave power. As a result, the MSN formed at $450 \mathrm{~W}$ displayed a more highly ordered structure (Figure 3). These differences in MSN characteristics were presumed to affect the adsorption and release pattern of ibuprofen.

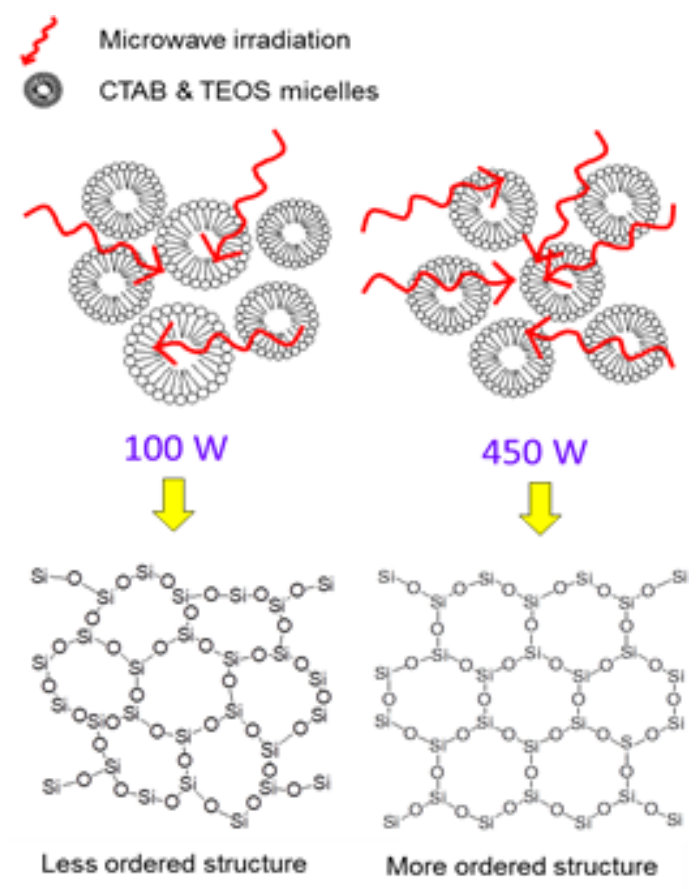

Figure 3. Formation of hexagonal order of $\mathrm{MSN}_{100}$ and $\mathrm{MSN}_{450}$

Ibuprofen was used as a model drug to evaluate the adsorptivity and drug storage ability of the synthesized MSNs (Figure $4 \mathrm{a}$ ). $\mathrm{MSN}_{450}$ displayed the highest adsorption rate at the first 6 hours and almost complete adsorption was achieved with $98.3 \%$ adsorption after 7 hours. The $\mathrm{MSN}_{300}$ and $\mathrm{MSN}_{100}$ demonstrated almost similar pattern of adsorption with $81.3 \%$ and $74.1 \%$, respectively. Although the MSNs had almost the same chemical structure, ibuprofen adsorption increased with an increase in the microwave power used during MSN synthesis. This result implies that the differences in the material properties resulted in variable ibuprofen adsorption behavior. 


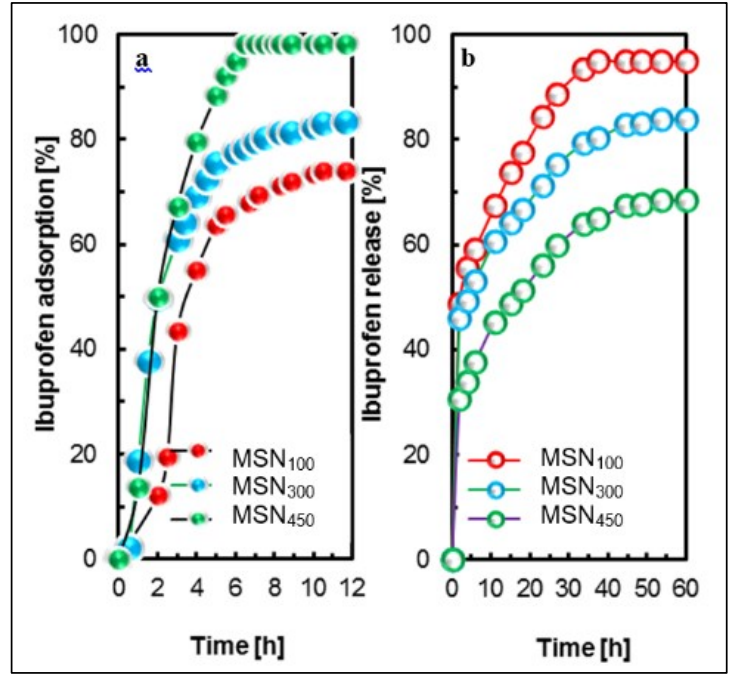

Figure 4. Adsorption (a) and release (b) of ibuprofen by all MSNs

Based on the characterization by TEM and FESEM, the variation in microwave power led to dissimilar patterns in the material's structure. In parallel with the crystallinity, increasing the microwave power also resulted in the enhancement of hexagonal order and the range of the silica. The complete adsorption of ibuprofen by $\mathrm{MSN}_{450}$ was probably caused by the higher surface area and fewer irregularities in the morphology that resulted in a more accessible surface as compared to $\mathrm{MSN}_{300}$ and $\mathrm{MSN}_{150}$.

It is of great importance to comprehensively understand the drug delivery profiles using in vitro simulated body fluid (SBF) before creating a suitable controlled formulation of mesoporous silica materials for use in vivo. The concentration of ibuprofen released in SBF as a function of time was determined by monitoring changes in the absorbance by UV-Vis spectroscopy at a wavelength of $264 \mathrm{~nm}$. The release rates are shown in Figure 4b. The ibuprofen released fastest from $\mathrm{MSN}_{100}$, followed by $\mathrm{MSN}_{300}$ and $\mathrm{MSN}_{450}$. $\mathrm{MSN}_{450}$ displayed the slowest release rate of ibuprofen with only $65 \%$ of the release percentage of $\mathrm{MSN}_{300}$ and $\mathrm{MSN}_{100}$ within the same contact time. The ibuprofen release of $\mathrm{MSN}_{300}$ and $\mathrm{MSN}_{100}$ were $81 \%$ and $95 \%$ release, respectively. $\mathrm{MSN}_{100}$, with a less ordered silica arrangement, showed the highest release percentage and the fastest drug release rate before equilibrium was reached.

Since the pore surface chemistry of the mesoporous silica was quite similar, it is presumed that the difference in drug delivery behavior may be reasonably attributed to the pore structure of the MSN structure. In fact, a similar pore diameter and drug molecule size allows for sustained release owing to the size confinement effect; thus, the loaded drug can be released at a relatively high rate when the pore size of the MSN is much larger than the size of the drug molecule [16].

On the contrary, MSN-MW $\mathrm{M}_{40}$, which is presumed to have the largest and similar average pore distribution due to its most ordered structure did not exhibit the fastest release rate. This observation demonstrated the presence of diffusion process constraints during the release process, probably influenced by the pathway (the channel length of silica) of mesoporous silica, as discussed in the XRD characterization. The long ordered channels of $\mathrm{MSN}_{450}$ retained ibuprofen molecules, rendering the rapid release of drug molecules from the surface unfavorable. In a similar report, fast ibuprofen release was observed with MCM-41, which was characterized by a short channel length [17]. Hence, the length of the pathway is one of the most important factors when investigating drug delivery behavior, in addition to other factors such as the pore size, surface chemistry, and pore geometry of mesoporous silica. 
The phenomenon of the adsorption and release of ibuprofen molecules is proposed according to the XRD, FESEM, and TEM results. Increasing the microwave power was found to form enhanced hexagonal order and range of silica, which led to a greater surface area, pore width and pore volume. The fewer irregularities in the morphology and a better silica arrangement were found to improve ibuprofen adsorption.

\section{Conclusion}

The enhancement of crystal growth was observed in the formation of mesoporous silica nanoparticles synthesized with variable microwave power in the range of $100-450 \mathrm{~W}$. The use of low heating power $(100 \mathrm{~W})$ resulted in low crystallinity, an irregular mesoporous structure and a low surface area of $\mathrm{MSN}_{100}$, which on the contrary, highest heating power produced more crystallized and better silica arrangement. In relation to the adsorption properties, $\mathrm{MSN}_{450}$ demonstrated the highest ibuprofen adsorption (98.3\%), followed by $\mathrm{MSN}_{300}(81.3 \%)$ and $\mathrm{MSN}_{100}(74.1 \%)$, confirming that the difference in the material properties was a contributing factor in ibuprofen adsorption. By exhibiting the most crystallized structure, complete adsorption of ibuprofen by $\mathrm{MSN}_{450}$ was probably caused by fewer irregularities in its morphology that resulted in a more accessible surface compared to $\mathrm{MSN}_{300}$ and $\mathrm{MSN}_{150}$. In accordance, $\mathrm{MSN}_{450}$ showed the slowest release rate of adsorption due to its wide pore diameter and long range of silica order.

\section{Acknowledgement}

The authors are grateful for the financial support by the Research University Grant from Universiti Teknologi Malaysia (Grant No. 02H76), the awards of MyPhD Scholarship (Nur Hidayatul Nazirah Kamarudin) from Ministry of Higher Education, Malaysia, and to the Hitachi Scholarship Foundation for their support.

\section{References}

1. Sayari, A. and Hamoudi, S. (2001). Periodic mesoporous silica-based organic-inorganic nanocomposite materials. Chemistry of Materials, 13(10): $3151-3168$.

2. Liu, X., Li, J., Zhou, L., Huang, D. and Zhou, Y. (2005). Adsorption of $\mathrm{CO}_{2}, \mathrm{CH}_{4}$ and $\mathrm{N}_{2}$ on ordered mesoporous silica molecular sieve. Chemical Physics Letters, 415(4-6): 198 - 201.

3. Karim, A. H., Jalil, A. A., Triwahyono, S., Sidik, S. M., Kamarudin, N. H. N., Jusoh, R., Jusoh, N. W. C. and Hameed, B. H. (2012). Amino modified mesostructured silica nanoparticles for efficient adsorption of methylene blue. Journal of Colloid and Interface Science, 386(1): 307 - 314.

4. Yu, Q., Hui, J., Wang, P., Xu, B., Zhuang, J. and Wang, X. (2012). Hydrothermal synthesis of mesoporous silica spheres: Effect of the cooling process. Nanoscale, 4: $7114-7120$.

5. Newalkar, B. L., Olanrewaju, J. and Komarneni, S. (2001). Microwave-hydrothermal synthesis and characterization of zirconium substituted SBA-15 mesoporous silica. The Journal of Physical Chemistry B, 105: $8356-8360$.

6. Hwang, Y. K., Chang, J. S., Kwon, Y. U. and Park, S. E. (2004). Microwave synthesis of cubic mesoporous silica SBA-16. Microporous and Mesoporous Materials, 68: 21 - 27.

7. Jalil, A. A. Kurono, N. and Tokuda, M. (2002). Synthesis of the precursor of anti-inflammatory agents by cross-coupling using electrogenerated highly reactive zinc, Synthesis, 18: $2681-2686$.

8. Ballem, M. A., Cordoba, J. M. and Oden, M. (2010). Influence of synthesis temperature on morphology of SBA-16 mesoporous materials with a three-dimensional pore system. Microporous and Mesoporous Materials, 129: $106-111$.

9. Chen, B., Wang, Z., Quan, G., Peng, X., Pan, X., Wang, R., Xu, Y., Li, G. and Wu, C. (2012). In vitro and in vivo evaluation of ordered mesoporous silica as a novel adsorbent in liquisolid formulation. International Journal of Nanomedicine, 7: $199-209$.

10. Wu C. G. and Bein, T. (1996). Microwave synthesis of molecular sieve MCM-41. Chemical Communications, $925-926$.

11. Heikkila, T., Santos, H. A., Kumar, N., Murzin, D.Y., Salonen, J., Laaksonen, T., Peltonen, L., Hirvonen, J. and Lehto, V. P. (2010). Cytotoxicity study of ordered mesoporous silica MCM-41 and SBA-15 microparticles on Caco-2 cells. European Journal of Pharmaceutics and Biopharmaceutics, 74: 483 -494.

12. Acharya, S. and Singh, K. (2011). Microwave-assisted chemical reduction routes for direct synthesis of (fct) L10 Phase of Fe-Pt. Journal of Microwave Power Electromagnetic Energy, 45: 63 - 69.

13. Hayes, B. L. (2002). Microwave synthesis: Chemistry at the speed of light. CEM Publishing: Matthews, NC. 
14. Yu, C., Fan, J., Tian, B. and Zhao, D. (2004). Morphology development of mesoporous materials: a colloidal phase separation mechanism. Chemistry of Materials, 16: 889 - 898.

15. Cheng, H., Cheng, J., Zhang, Y. and Wang, Q. M. (2007). Large-scale fabrication of ZnO micro-and nanostructures by microwave thermal evaporation deposition. Journal of Crystal Growth, 299: $34-40$.

16. Qu, F., Zhu, G., Lin, H., Sun, J., Zhang, D., Li, S. and Qiu, S. (2006). Drug self-templated synthesis of ibuprofen/mesoporous silica for sustained release. European Journal of Inorganic Chemistry, 19: 3943 - 3947.

17. Qu, F., Zhu, G., Lin, H., Zhang, W., Sun, J., Li, S. and Qiu, S. (2006). A controlled release of ibuprofen by systematically tailoring the morphology of mesoporous silica materials. Journal of Solid State Chemistry. 179: $2027-2035$. 